\title{
PERKIN MEDAL AWARD
}

The Perkin Medal for I 915 was conferred on Edward Weston, Sc.D., LI.D., for his distinguished services in the field of Chemical Engineering and Metallurgy, at the regular meeting of the New York Section of the Society of Chemical Industry held at The Chemists' Club, January 22, I915.

Dr. Weston's pioneer work in the fields of nickel plating, dynamos, arc lights, incandescent lamps and flaments and his remarkable success in the invention and manufacture of standard electrical measuring apparatus, based on his alloy researches, were reviewed in addresses by Prof. Chandler, Dr. Leo H. Baekeland, Mr. Carl Hering, and by the medalist himself. Owing to illness, Dr. Weston had been unable to prepare a manuscript copy of his address and the version printed below was abstracted by the editors from their stenographic notes. The other addresses are presented in full herewith. [EDITOR.]

\section{INTRODUCTORY ADDRESS}

By G. W. THOMpson

LADIES AND GentLEMEN:

This is the annual gathering when the Perkin Medal Committee makes its presentation of the Perkin Medal. It is hardly necessary or even advisable that your Chairman tonight should do more than preside at this meeting. The speakers that will come after will go into detail concerning the work which leads up to this presentation. There is only one thing which has come to me which I am taking the liberty of presenting, hoping that in doing so I shall not anticipate anything that may be said later on. It would seem as though in the last fifteen or twenty years, during which great progress has been made in our electrochemical industries, that much of that progress has been dependent upon the proper measurement of currents and voltage, and the recipient of the medal tonight is one who has contributed particularly in laying the foundation for precision in electrochemical industry. Efficiency in this means a great deal. Efficiency in labor, efficiency in the utilization of materials, and especially efficiency in the utilization of power, and this final efficiency in the utilization of power would hardly have been possible at all without the development of precision testing instruments, with which we mostly know Dr. Weston and his connections.

The presentation of the medal, however, does not rest upon this, and while it is the thing which we are most apt to think of, and for that reason $I$ mention it at this time, his work in the chemical industry itself warrants us in the presenting of this medal.

The first speaker on our program is the senior American Past President of the Society of Chemical Industry, and I take much pleasure in asking Dr. Chandler, whom we 1l. love and revere, to begin the speeches of the evening.

129 YORK STREET BROOKL,XN

\section{PRESENTATION} ADDRESS

By C. F. Chanderer

Mr. Chatrman and Brother ChEMTSTS:

It is my privilege and very pleasant duty, as the senior Past-President of the Society of Chemical Industry, residing in this country, to present to Edward Weston, LL.D. and D.Sc, the ninth impression of the Perkin Medal, in recognition of his most valuable work in applied chemistry.

Dr. Weston has worked upon a great variety of subjectschemical, electrical and mechanical-and in each of these fields he has been led to most important discoveries which have been promptly recognized and as promptly applied in their respective uses. Prominent among these are his improvements in nickel plating, in the application of dynamos as substitutes for galvanic batteries in electroplating, electrotyping, ete, the Weston standard cell, the flaming arc, the structureless carbon filaments for incandescent electrical lighting, and resistance alloys for electrical measuring instruments.

It is not my purpose to give the details of the varied discoveries and inventions of Dr. Weston, as Dr. Baekeland will follow me and set forth more particularly their nature.

Dr. Weston was born on May 9, I850, at Brynn Castle, near Oswestry, Shropshire, England. While he was still a lad, his father moved to Wolverhampton in Staffordshire. There he was educated under private tutors. He received his first in- 